\title{
RAZÓN DE LAS OCHO PIEZAS QUE SE RECOGIERON EN LA MALOCA DE PAICAVÍ... (1669)
}





\section{RAZÓN DE LAS OCHO PIEZAS QUE SE RECOGIERON EN LA MALOCA DE PAICAVÍ Y SU VENCINDAD QUE TRUJE A ESTA CIUDAD DE LA CONCEPCIÓN DE ORDEN DEL SARGENTO MAYOR D. MELCHOR DE CÁRDENAS, Y SE ENTREGUE EN PRESENCIA DEL SARGENTO VILLO EN LA FORMA SIGUIENTE ${ }^{1}$}

Una india mujer de Puelcan de Arauco el cual la regato[sic] por unas sobrina suya que dio en su lugar, la mujer de Anculue=que pertenece al cacique Paylaguala.

Una sobrina del cacique Lientur que llaman LaMofrodita [sic] de tierras de Paycavi que toca al dicho Cacique

Otra india mujer del cacique Curanao de Paicavi que se [regato] por un hijo de la dicha india de tierras de Coreura, toca al dicho cacique

Un indio llamado llancaman de tierras de Quedico que por ser casado por la Yglesia le cojieron a su Mujer se devolvió que por ella dio otra india de tierra de Quedico con una cria de dos años, pertenece, al cacique Perquilao

Un muchacho de trece a catorce años llamado Quechatoque de tierras de Colcura de los que cojieron en Tomelmo que hoy le tiene doña Thomasa de Rojas pertenece al cacique Curanao.

Una india del cacique Guenchupan su mujer con una cria de un año que llevaron a Santiago, pertenece al cacique dicho

Una india mujer de Quentepan de tierras de Paicavi pertenece al cacique Lientur-

Que con las dos crías vienen a ser nueve piezas las cuales como dicho es truje a esta ciudad de orden del dicho sargento mayor d. Melchor de Cárdenas a quien se las entregué, y de su orden al sargento Villo lo cual es así verdad y así lo juro a Dios y a una Cruz que por no saber firmar ruego a VM testigo lo firme por mí en la Concepción a quince de marzo de seiscientos y sesenta y nueve-

Por el Capitán Pedro Farfán, Francisco Cortés.

1. Documento contenido en la foja 77 del "Segundo cuaderno, de las diligencias fechas en la ciudad de la Concepción sobre los procedimientos del Señor Gobernador, Don Francisco de Meneses. Jues Visitador el señor licenciado Dn. Lope Antonio de Munives caballero de la orden de Alcántara oidor de las Real Audiencia y cancillería de la Ciudad de los Reyes. Escribanos Francisco Muñoz de Alba". Pieza tercera. Año de 1669. En Archivo General de Indias, Escribanía, 937 A. Residencias Audiencia de Chile. Residencia de Francisco de Meneses, gobernador, capitán general y Presidente de la Audiencia de Chile, por Lope Antonio de Munibe, oidor de la Audiencia de Lima. Fenecida en 1676. Transcripción de Alejandra Araya Espinoza. 